\title{
Variable plastron coloration of the eastern painted turtles Chrysemys picta picta in a single locality of south-eastern Massachusetts, USA
}

\author{
THILINA SURASINGHE*, REGINA CHRISTEN, ALLY DEWEY, ALEXIS GOUTHRO, KIM TOCCHIO, \\ BRETT SHEEHAN, TAYLOR MCCULLEY, \& YACOUB DOBEIB
}

${ }^{1}$ Department of Biological Sciences, Brightwater State University, Bridgewater, Massachusetts 02325, USA

${ }^{*}$ Corresponding author e-mail: tsurasinghe@bridgew.edu

$B^{\text {ats }}$ dy coloration of animals is a complex morphological trait produced by biochemical and biophysical interactions under genetic control, which can be triggered by environmental influences (Brejcha et al., 2019, Rowe et al., 2006). Conspicuous body colours may signal vital information both between and within species, including sexual selection, mate recognition, conspecific identification, kin recognition, and predator deterrence (McGaugh, 2008) while pigmentation resulting in background-matching helps camouflage (McGaugh, 2008, Reinke et al., 2017, Rowe et al., 2014). Histological and physiological processes of colour production as well as environmental determinants of colour variations have been substantially explored among emydid turtles (Brejcha et al., 2019, McGaugh, 2008, Rowe et al., 2014). These turtles develop variable colours by assimilating dissolved substances from their aquatic environments (Rowe et al., 2016, Rowe et al., 2013). Mostly limited to anecdotal accounts, such observations are rarely documented in the scientific literature.

The colour variations among emydids occur particularly on their limbs, head, carapace, and plastron. Here, we documented the presence of multiple plastron colour variations in the eastern painted turtles, Chrysemys picta picta (Schneider, 1783). This species is among the most common and widely distributed chelonian of North America, ranging from southern Canada to northern Mexico, and occupies a diverse range of freshwater and wetland habitats such as ponds, lakes, rivers, streams, freshwater marshes, forested and scrub swamps (Ernst, 1971; Ernst \& Lovich, 2009).

At Mass Audubon's Tidmarsh Wildlife Sanctuary, Plymouth Massachusetts, USA, we documented different plastron colorations among different individuals of $C$. p. picta. Yellow and red stripes on legs, and the prominent yellow spot behind the eye, were the identification features we used. Turtles were captured on 24 June 2018 and on four occasions between 7-26 June 2019 via large Promar Collapsible Minnow Traps deployed at a coastal, low-gradient headwater wetland $\left(41.90117^{\circ} \mathrm{S},-70.57131^{\circ} \mathrm{W}, \mathrm{WGS} 84,3.96 \mathrm{~m}\right.$ elev.) where the substrate was a thick layer of decomposing vegetation, peat, and slit. The study site was formally a cranberry farm, now restored into a wetland-aquatic habitat complex.

We captured three turtles with black plastrons where
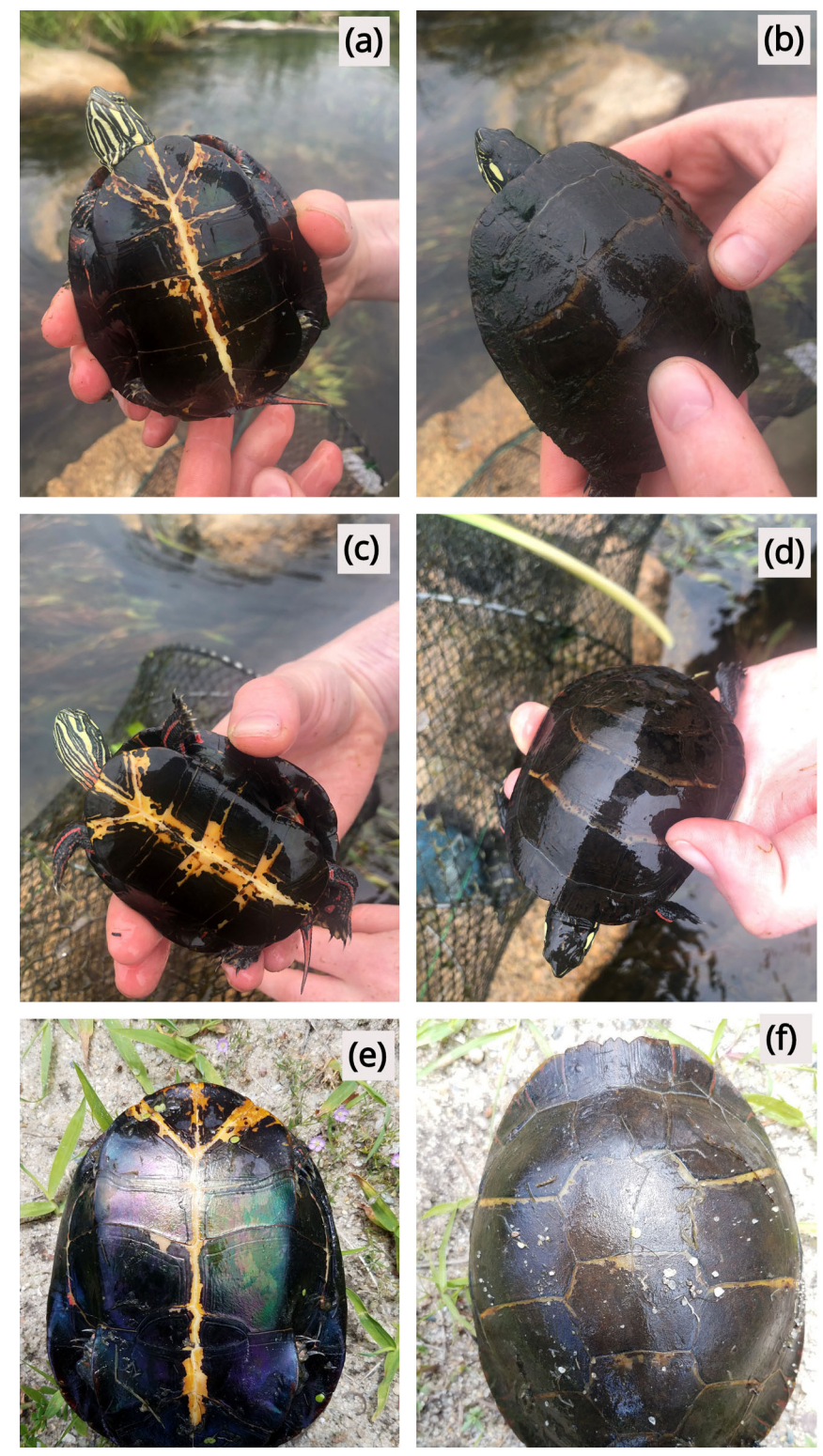

Figure 1. Plastrons and carapaces of three C. p. picta, captured at Mass Audubon's Wildlife Sanctuary. Each row of the panel is represents the same individual. The plastrons of all these individuals are predominantly black.

the typical plain-yellow coloration was only visible along the plastron sutures (Fig. 1). The black colour extended 

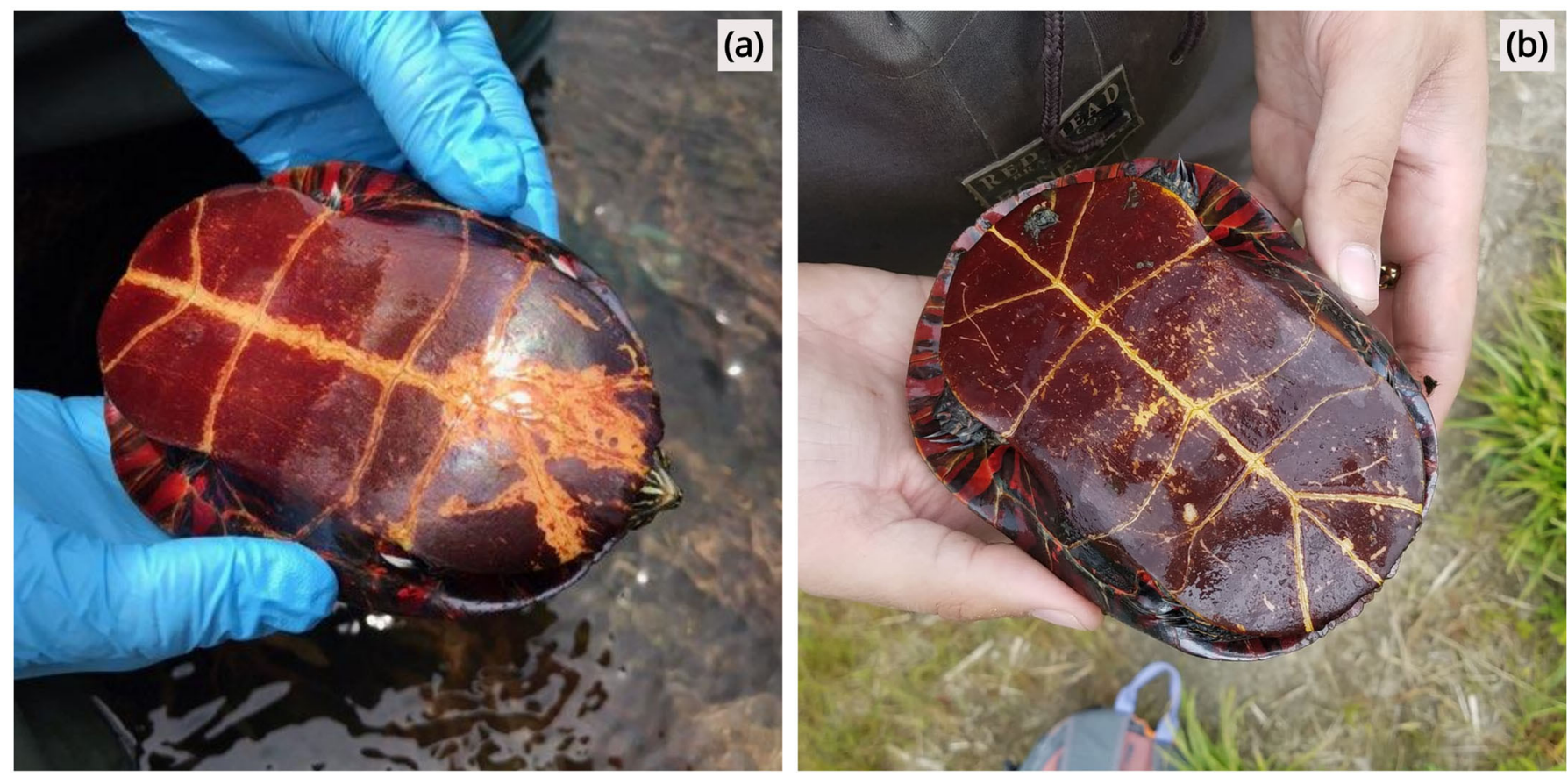

Figure 2. Two individual C. p. picta with predominantly reddish-brown plastrons, captured at Mass Audubon's Wildlife Sanctuary

throughout the plastron (except sutures), up to the plastron edge and the hinges. This coloration is likely superficial as evident by its flaky appearance. In some individuals, the plastrons appeared iridescent. Three more turtles had reddish-brown plastrons (Fig. 2) while another had a bright red plastron. Unlike the black plastrons, the reddish-brown and bright red colorations were deeply pigmented into the scutes. The carapace, head, and limbs of turtles with black plastrons were comparatively darker while the red-yellow stripes and spots appeared much brighter. During the twoyear period, we captured over 50 painted turtles in the same area; no other turtles captured had colour aberrations.

In general, eastern painted turtles have plain yellow plastrons and olive green or black carapaces (Ernst \& Lovich, 2009, Powell et al., 2016). Throughout their range, substantial variations have been observed in plastral background colour, ranging from beige to orange or red, as well as different patterns such as dark spots or blotches of variable sizes and shapes (Cohen, 1992, Hulse et al., 2001). Similarly, light-todark hue variations in carapace have also been observed among painted turtles. Although plastral colour variations are not unknown, the presence of multiple colour morphs in the same locality is noteworthy. Colour variations among eastern painted turtles are attributed to among-subspecies phenotypic differences and geographic variations, thus, conservative colorations are generally expected for a subspecies occupying a certain habitat or a watershed (Ernst et al., 2015; Groves, 1983). Turtle integument colour arises from differential arrangements of chromatophores, variable concentration of melanosomes, or melanin deposition in keratinocytes (Rowe et al., 2013). While our observation on integument darkening is probably attributable to the latter two mechanisms, diffusion of tannins and irons could have resulted in the black plastrons. Higher concentrations of dissolved tannins and iron have also been documented in our study region (Burns, 2017; National Water Quality Monitoring Council, 2019). Exoskeletal absorption of minerals has been documented for other emydids (Lovich et al., 1990).

The wetland we surveyed is rich in tannin sources such as peat deposits and partially-decomposed vegetation (Burns, 2017). Iron mining and refining, a likely source of dissolved iron, was prominent in our study region in the early-industrial era. The wetland surveyed was an irrigation reservoir where iron and tannins could have accumulated within the substrates. Recent restoration interventions and dam removal may have re-suspended these solutes into the water column, which may then have been assimilated into the turtle integument. Dietary carotenoids could have resulted in both red-brown plastral colorations and brighter stripes and spots (Reinke et al., 2017, Steffen et al., 2019).

In the future, surveying similar habitats within the painted-turtle range will reveal geographical patterns and relative frequencies of these colour anomalies.

Conspicuous coloration of the head and limbs may serve as ornamental advertisement or honest signaling of high fitness in mate selection (Polo-Cavia et al., 2013, Steffen et al., 2019, Steffen et al., 2015). However, since painted turtles are not sexually dichromatic, the conspicuous colours we documented are an unlikely driver of mate choice. Painted turtles are quasi-social species, thus, these colorations may help conspecific recognition (Steffen et al., 2019). Plastral and carapace darkening may improve camouflage by increasing background-colour convergence, which could reduce predation rates (Rowe et al., 2016; Steffen et al., 2015). We detected several turtle predators in our study area: red foxes, coyotes, raccoons, crows, bullfrogs, and common garter snakes. Reversible melanisation for both backgroundcolour convergence (Rowe et al., 2016) and efficient thermoregulation have been observed among emydid turtles (Cao et al., 2019; Rowe et al., 2009). In northern latitudes, 
such as our study site with cooler spring air temperatures and a shorter growing season, darker integument may help achieve more favourable body temperatures and hence boost metabolism.

\section{ACKNOWLEDGEMENTS}

This study was permitted by Massachusetts Division of Fisheries and Wildlife (Permit No 088.19SCRA) and approved by IACUC of Bridgewater State University (permit No 201906). We thank Mass Audubon for granting access to this study site and Tidmarsh Living Observatory for various support provided.

\section{REFERENCES}

Brejcha, J., Bataller, J.V., Bosakova, Z., Geryk, J., Havlikova, M., Kleisner, K., Marsik, P., Font, E. (2019). Body coloration and mechanisms of colour production in Archelosauria: The case of deirocheline turtles. Royal Society Open Science 6: 190319 https://doi.org/10.1101/556670.

Burns, M. 2017. A Rapid Assessment for Cranberry Farm Wetland Restoration Potential in Southeastern and Cape Cod Massachusetts. Masters Thesis, Antioch University New England, $97 \mathrm{pp}$.

Cao, D., Ge, Y., Wei, Y., Duan, H. \& Gong, S. (2019). Observations on carapace color change in the juvenile big-headed turtle (Platysternon megacephalum). PeerJ 7:e7331.

Cohen, M. (1992). The Painted Turtle, Chrysemys picta. Tortuga Gazette 28: 1-3.

Ernst, C.H. (1971). Chrysemys picta. Catalogue of American Amphibians and Reptiles 106: 1-4.

Ernst, C.H. \& Lovich, J.E. (2009). Turtles of the United States and Canada. Baltimore: John Hopkins University Press, $840 \mathrm{pp}$.

Ernst, C.H., Orr, J.M., Laemmerzahl, A.F. \& Creque, T.R. (2015). Variation and zoogeography of the turtle Chrysemys picta in Virginia, USA. Herpetological Bulletin 130: 9-15.

Groves, J.D. (1983). Taxonomic Status and Zoogeography of the Painted Turtle Chrysemys picta (Testudines: Emydidae), in Maryland. American Midland Naturalist 109: 274-279.

Hulse, A.C., McCoy, C.J. \& Censky, E.J. (2001). Amphibians and Reptiles of Pennsylvania and the Northeast. Ithaca: Connell University Press, 419 pp.

Lovich, J., McCoy, C. \& Garstka, W. (1990). The development and significance of melanism in the slider turtle. In Life History and Ecology of the Slider Turtle, 233-254pp. Gibons J.W. (Ed.). Washington DC: Smithsonian Institution Press.

McGaugh, S.E. (2008). Color variation among habitat types in the spiny softshell turtles (Trionychidae: Apalone) of Cuatrociénegas, Coahuila, Mexico. Journal of Herpetology 42: 347-354.
National Water Quality Monitorig Concil. (2019). Water Quality Portal. United States Geological Survey and United States Environmental Protection Agency, https:// www.epa.gov/waterdata/water-quality-data-wqx.

Polo-Cavia, N., López, P., Martín, J. (2013). Head coloration reflects health state in the red-eared slider Trachemys scripta elegans. Behavioral Ecology and Sociobiology 67: 153-162.

Powell R., Conant R. \& Collins J.T. (2016). Peterson Field Guide to Reptiles and Amphibians of Eastern and Central North America. Boston: Houghton Mifflin Harcourt, 494 pp.

Reinke, B.A., Calsbeek, R. \& Stuart-Fox, D. (2017). A test of an antipredatory function of conspicuous plastron coloration in hatchling turtles. Evolutionary Ecology 31: 463-476.

Rowe, J.W., Bunce, C.F. \& Clark, D.L. (2014). Spectral reflectance and substrate color-induced melanization in immature and adult Midland painted turtles (Chrysemys picta marginata). Amphibia-Reptilia 35: 149-159.

Rowe, J.W., Clark, D.L., Mortensen, R.A., Commissaris, C.V., Wittle, L.W. \& Tucker, J.K. (2016). Thermal and substrate color-induced melanization in laboratory reared redeared sliders (Trachemys scripta elegans). Journal of Thermal Biology 61: 125-132.

Rowe, J.W., Clark, D.L., Price, M. \& Tucker, J.K. (2009). Reversible melanization following substrate color reversal in midland painted turtles (Chrysemys picta marginata) and red-eared sliders (Trachemys scripta elegans). Journal of Herpetology 43: 402-409.

Rowe, J.W., Clark, D.L., Ryan, C. \& Tucker, J.K. (2006). Effect of substrate color on pigmentation in Midland painted turtles (Chrysemys picta marginata) and red-eared slider turtles (Trachemys scripta elegans). Journal of Herpetology 40: 358-364.

Rowe, J.W., Clark, D.L., Shaw, D.M. \& Wittle, L.W. (2013). Histological basis of substrate color-induced melanization and reversal of melanization in Painted Turtles (Chrysemys picta marginata). Chelonian Conservation and Biology 12: 246-251.

Steffen, J.E., Hultberg, J., Drozda, S. (2019). The effect of dietary carotenoid increase on painted turtle spot and stripe color. Comparative Biochemistry and Physiology Part B: Biochemistry and Molecular Biology 229: 10-17.

Steffen, J.E., Learn, K.M., Drumheller, J.S., Boback, S.M. \& McGraw, K.J. (2015). Carotenoid composition of colorful body stripes and patches in the painted turtle (Chrysemys picta) and red-eared slider (Trachemys scripta). Chelonian Conservation and Biology 14: 56-63.

Accepted: 25 September 2019 